\title{
Differences in Phenology and Reserve Carbohydrate Concentrations Between Dormant and Nondormant Production Systems in Southern Highbush Blueberry
}

\author{
P.A.W. Swain and R.L. Darnell \\ Horticultural Sciences Department, University of Florida, Gainesville, FL 32611
}

AdDitional INDEX wORDs. flower bud initiation, fruit growth, source-sink, Vaccinium corymbosum interspecific hybrid

\begin{abstract}
Aвstract. Two cultivars of southern highbush blueberry (Vaccinium corymbosum L. interspecific hybrid), 'Sharpblue' and 'Wannabe', were container-grown outside in either a dormant or nondormant production system to determine how the two production systems affected carbohydrate $\left(\mathrm{CH}_{2} \mathrm{O}\right)$ status, growth, and development. Plants were maintained in the nondormant condition by continuous $\mathrm{N}$ fertilization throughout winter (average maximum/minimum temperatures of $17 / 5^{\circ} \mathrm{C}$ ). Plants in the nondormant system retained their foliage longer into the winter compared with plants in the dormant system. Flower bud number, density, fruit number, and total fruit fresh weight $(F W)$ per plant were greater in the nondormant compared with the dormant system plants for both cultivars. Mean fruit FW was greater in dormant compared with nondormant 'Wannabe' plants, while in 'Sharpblue', mean fruit FW was similar in both systems. Cane and root $\mathrm{CH}_{2} \mathrm{O}$ concentrations in nondormant system plants were generally similar to or lower than those measured in dormant system plants. Assuming that longer leaf retention in nondormant system plants increased $\mathrm{CH}_{2} \mathrm{O}$ synthesis compared with dormant system plants, the patterns of reproductive/vegetative development and $\operatorname{root} / \mathrm{shoot}_{\mathrm{CH}} \mathrm{O}$ concentrations indicate that the increased $\mathrm{CH}_{2} \mathrm{O}$ in nondormant system plants was allocated to increased reproductive growth in lieu of $\mathrm{CH}_{2} \mathrm{O}$ reserve accumulation. It is probable that this increased $\mathrm{CH}_{2} \mathrm{O}$ availability, combined with longer perception of short days due to longer leaf retention, were major factors in increasing flower bud initiation and yield in the nondormant compared with the dormant system plants.
\end{abstract}

Chilling accumulation is a major limitation to extending deciduous fruit production into subtropical and tropical areas. In traditional deciduous fruit production areas, plants enter endodormancy in the fall and accumulate chill hours during the winter. Upon chilling satisfaction, floral and vegetative buds are released from endodormancy and budbreak occurs when environmental conditions permit. Insufficient chilling results in delayed, protracted, and reduced budbreak and fruit development. Blueberry plants (Vaccinium sp.) can be prevented from entering endodormancy if they are fertilized continuously with $\mathrm{N}$ and protected from freezing temperatures (Reeder et al., 1994, 1998). Under these conditions, flowering and fruit development occur in the spring without a dormant period or chilling (Reeder et al., 1998; Sharpe and Sherman, 1971). This nondormant production system for blueberry has been used in the subtropics to avoid endodormancy and the concomitant chill requirement (Reeder et al., 1998).

In the nondormant production system, year-round $\mathrm{N}$ fertilization enables blueberry plants to maintain their foliage longer into the fall and winter, compared with plants in the dormant production system. However, differences in growth and yield between the two systems are unknown since side-by-side comparisons have not been made. It is likely that the longer photosynthetic season experienced by nondormant compared with dormant system plants would alter the carbohydrate $\left(\mathrm{CH}_{2} \mathrm{O}\right)$ status of plants (e.g., timing or extent of reserve accumulation), which in turn, may affect vegetative and/or reproductive growth. In warm winter climate areas, either production system can be used, thus, it is important to compare blueberry growth and yield between the two systems.

The hypothesis tested in the present experiment was that the increased length of the photosynthetic season in the nondormant plants will increase $\mathrm{CH}_{2} \mathrm{O}$ availability and therefore increase fruit yield the following season, compared with plants in the dormant system. The specific objectives were to 1) compare vegetative and reproductive development between the two systems, and 2) determine the effect of production system on the $\mathrm{CH}_{2} \mathrm{O}$ status at various phenological stages.

Table 1. Calendar dates and phenological stages for whole-plant harvests of 'Sharpblue' and 'Wannabe' southern highbush blueberry

\begin{tabular}{|c|c|c|c|c|}
\hline \multirow[b]{2}{*}{ Phenological stage ${ }^{z}$} & \multicolumn{2}{|c|}{ 'Sharpblue' } & \multicolumn{2}{|c|}{ 'Wannabe' } \\
\hline & Dormant & Nondormant & Dormant & Nondormant \\
\hline Pre-FBI & 3 Oct. 1996 & 3 Oct. 1996 & 12 Oct. 1996 & 12 Oct. 1996 \\
\hline FBI & 27 Dec. 1996 & 27 Dec. 1996 & 28 Dec. 1996 & 28 Dec. 1996 \\
\hline $50 \%$ Bloom & 1 Feb. 1997 & 17 Jan. 1997 & no harvest & no harvest \\
\hline $50 \%$ Fruit set & 6 Apr. 1997 & 5 Mar. 1997 & 16 Apr. 1997 & 17 Apr. 1997 \\
\hline Fruit harvest & 10 June 1997 & 11 June 1997 & 27 May 1997 & 28 May 1997 \\
\hline
\end{tabular}

${ }^{\mathrm{z}} \mathrm{Pre}-\mathrm{FBI}=$ before flower bud initiation and differentiation, FBI $=$ after flower bud initiation and differentiation, bloom $=50 \%$ of the flower buds were open, fruit set $=50 \%$ of the flower buds that opened set fruit, and fruit harvest $=$ immediately after final fruit harvest.

Received for publication 28 Apr. 2000. Accepted for publication 12 Mar. 2001. Florida Agricultural Experiment Station journal series R-07989. The cost of publishing this paper was defrayed in part by the payment of page charges. Under postal regulations, this paper therefore must be hereby marked advertisement solely to indicate this fact. 
Table 2. Vegetative growth of 'Sharpblue' southern highbush blueberry in the dormant (D) and nondormant (ND) production systems at each wholeplant phenological harvest $(\mathrm{n}=4)$; DNT $=$ data not taken.

\begin{tabular}{|c|c|c|c|c|c|c|c|c|c|c|}
\hline \multirow{2}{*}{$\begin{array}{l}\text { Phenological } \\
\text { stage }^{\mathrm{z}}\end{array}$} & \multirow[b]{2}{*}{ System } & \multirow{2}{*}{$\begin{array}{l}\text { Harvest } \\
\text { date }\end{array}$} & \multicolumn{2}{|c|}{ Leaf area $\left(\mathrm{cm}^{2}\right)$} & \multicolumn{2}{|c|}{ Leaf dry wt (g) } & \multicolumn{2}{|c|}{ New cane } & \multirow{2}{*}{$\begin{array}{l}\text { Root dry } \\
\text { wt (g) }\end{array}$} & \multirow{2}{*}{$\begin{array}{c}\text { Plant vol } \\
\left(\mathrm{m}^{3}\right)\end{array}$} \\
\hline & & & Old & New & Old & New & Length $(\mathrm{cm})$ & $\mathrm{DW}(\mathrm{g})$ & & \\
\hline$\overline{\text { Pre-FBI }}$ & None & 3 Oct. 1996 & $9,659.4 \mathrm{a}^{\mathrm{y}}$ & $--^{x}$ & $88.1 \mathrm{a}$ & --- & --- & --- & $95.8 \mathrm{a}$ & $0.40 \mathrm{~b}$ \\
\hline \multirow[t]{2}{*}{ FBI } & $\mathrm{D}$ & 27 Dec. 1996 & 2,097.1 $\mathrm{cd} \mathrm{B}^{\mathrm{w}}$ & --- & $22.3 \mathrm{c} \mathrm{B}$ & --- & --- & --- & $136.5 \mathrm{a} \mathrm{A}$ & DNT \\
\hline & ND & 27 Dec. 1996 & $5,496.2 \mathrm{~b} \mathrm{~A}$ & --- & $63.1 \mathrm{~b} \mathrm{~A}$ & --- & --- & --- & $134.2 \mathrm{a} \mathrm{A}$ & DNT \\
\hline \multirow[t]{2}{*}{$50 \%$ Bloom } & $\mathrm{D}$ & 1 Feb. 1997 & $522.5 \mathrm{de} \mathrm{B}$ & $9.2 \mathrm{~d} \mathrm{~A}$ & $5.5 \mathrm{~cd} \mathrm{~B}$ & $0.1 \mathrm{~d} \mathrm{~A}$ & --- & --- & $127.3 \mathrm{a} \mathrm{A}$ & 0.70 a A \\
\hline & ND & 17 Jan. 1997 & $3,721.8$ bc A & $0.0 \mathrm{~d} \mathrm{~B}$ & $45.5 \mathrm{~b} \mathrm{~A}$ & $0.0 \mathrm{~d} \mathrm{~B}$ & --- & --- & $128.0 \mathrm{a} \mathrm{A}$ & $0.48 \mathrm{~b} \mathrm{~B}$ \\
\hline \multirow[t]{2}{*}{$50 \%$ Fruit set } & $\mathrm{D}$ & 6 Apr. 1997 & 67.1 e B & $4,050.4 \mathrm{c} \mathrm{A}$ & $0.7 \mathrm{~d} \mathrm{~B}$ & $32.4 \mathrm{c} \mathrm{A}$ & --- & --- & 128.7 a A & 0.65 a A \\
\hline & ND & 5 Mar. 1997 & $1,235.0$ de $\mathrm{A}$ & $812.3 \mathrm{~d} \mathrm{~B}$ & $13.0 \mathrm{~cd} \mathrm{~A}$ & $4.4 \mathrm{~d} \mathrm{~A}$ & --- & --- & $101.0 \mathrm{a} \mathrm{A}$ & $0.63 \mathrm{a} \mathrm{A}$ \\
\hline \multirow[t]{2}{*}{ Fruit harvest } & $\mathrm{D}$ & 10 June 1997 & 41.7 e A & 7,389.9 b B & $0.4 \mathrm{~d} \mathrm{~A}$ & $62.7 \mathrm{~b} \mathrm{~A}$ & $731.8 \mathrm{~A}$ & $19.0 \mathrm{~B}$ & 127.8 a A & 0.77 a A \\
\hline & ND & 11 June 1997 & 26.9 e A & $10,555.5$ a A & $0.3 \mathrm{~d} \mathrm{~A}$ & 99.8 a A & $1,110.0 \mathrm{~A}$ & $37.4 \mathrm{~A}$ & 102.0 a B & 0.77 a A \\
\hline
\end{tabular}

$\overline{{ }^{2}}$ Pre-FBI $=$ before flower bud initiation and differentiation, $\mathrm{FBI}=$ after flower bud initiation and differentiation, bloom $=50 \%$ of the flower buds were open, fruit set $=50 \%$ of the flower buds that opened set fruit, and fruit harvest $=$ immediately after final fruit harvest.

yLower case letters indicate mean separation within columns across phenological stages and production systems by Duncan's multiple range test, $P \leq$ 0.05 , except for plant volume, where $P \leq 0.10$.

${ }^{x}$ Dashes indicate no new growth at these phenological stages.

${ }^{\text {w}}$ Upper case letters indicate mean separation between production systems within a phenological stage by paired $t$ test, $P \leq 0.05$.

Table 3. Vegetative growth of 'Wannabe' southern highbush blueberry in the dormant (D) and nondormant (ND) production systems at each whole-plant phenological harvest $(n=4)$; DNT $=$ data not taken.

\begin{tabular}{|c|c|c|c|c|c|c|c|c|c|c|}
\hline \multirow{2}{*}{$\begin{array}{l}\text { Phenological } \\
\text { stage }^{\mathrm{z}}\end{array}$} & \multirow[b]{2}{*}{ System } & \multirow{2}{*}{$\begin{array}{c}\text { Harvest } \\
\text { date }\end{array}$} & \multicolumn{2}{|c|}{ Leaf area $\left(\mathrm{cm}^{2}\right)$} & \multicolumn{2}{|c|}{ Leaf dry wt (g) } & \multicolumn{2}{|c|}{ New cane } & \multirow{2}{*}{$\begin{array}{c}\text { Root dry } \\
\text { wt (g) }\end{array}$} & \multirow{2}{*}{$\begin{array}{c}\text { Plant vol } \\
\left(\mathrm{m}^{3}\right)\end{array}$} \\
\hline & & & Old & New & Old & New & Length (cm) & $\overline{\mathrm{DW}}(\mathrm{g})$ & & \\
\hline$\overline{\text { Pre-FBI }}$ & None & 12 Oct. 1996 & $10,162.0 \mathrm{a}^{\mathrm{y}}$ & $--^{x}$ & $127.6 \mathrm{a}$ & -- & -- & $\begin{array}{l}-- \\
-\end{array}$ & $125.1 \mathrm{a}$ & $\overline{0.90 \mathrm{a}}$ \\
\hline \multirow[t]{2}{*}{ FBI } & $\mathrm{D}$ & 28 Dec. 1996 & $1,848.2 \mathrm{c} \mathrm{B}^{\mathrm{w}}$ & --- & $21.4 \mathrm{c} \mathrm{B}$ & --- & --- & --- & $204.3 \mathrm{a} A$ & DNT \\
\hline & ND & 28 Dec. 1996 & $6,842.6 \mathrm{~b} \mathrm{~A}$ & --- & $77.5 \mathrm{~b} \mathrm{~A}$ & --- & --- & --- & $178.0 \mathrm{a} \mathrm{A}$ & DNT \\
\hline \multirow[t]{2}{*}{$50 \%$ Bloom $^{w}$} & $\mathrm{D}$ & --- & --- & --- & --- & --- & --- & --- & --- & --- \\
\hline & ND & --- & --- & --- & --- & --- & --- & --- & --- & --- \\
\hline \multirow[t]{2}{*}{$50 \%$ Fruit set } & $\mathrm{D}$ & 16 Apr. 1997 & $43.4 \mathrm{c} \mathrm{A}$ & $3,879.0$ a A & $0.6 \mathrm{~d} \mathrm{~A}$ & $26.2 \mathrm{a} \mathrm{A}$ & --- & --- & 161.7 a A & $0.93 \mathrm{a} \mathrm{A}$ \\
\hline & ND & 17 Apr. 1997 & 195.8 c A & $1,044.0 \mathrm{a} \mathrm{A}$ & $2.8 \mathrm{~d} \mathrm{~A}$ & $6.4 \mathrm{a} \mathrm{A}$ & --- & --- & 127.6 a A & $1.10 \mathrm{a} \mathrm{A}$ \\
\hline \multirow[t]{2}{*}{ Fruit harvest } & $\mathrm{D}$ & 27 May 1997 & $2.2 \mathrm{c} \mathrm{A}$ & $7,570.0$ a A & $0.0 \mathrm{~d} \mathrm{~A}$ & 82.2 a A & 994.5 a A & $24.1 \mathrm{a} \mathrm{A}$ & 147.5 a A & $1.00 \mathrm{a} \mathrm{A}$ \\
\hline & ND & 28 May 1997 & $255.9 \mathrm{c} \mathrm{A}$ & $7,574.0$ a A & $2.8 \mathrm{~d} \mathrm{~A}$ & $61.0 \mathrm{a} \mathrm{A}$ & 849.0 a A & $18.1 \mathrm{a} \mathrm{A}$ & 146.1 a A & 0.90 a A \\
\hline
\end{tabular}

${ }^{2}$ Pre-FBI $=$ before flower bud initiation and differentiation, FBI $=$ after flower bud initiation and differentiation, bloom $=50 \%$ of the flower buds were open, fruit set $=50 \%$ of the flower buds that opened set fruit, and fruit harvest $=$ immediately after final fruit harvest.

'Lower case letters indicate mean separation within columns across phenological stages and production systems by Duncan's multiple range test, $P \leq$ 0.05 .

${ }^{x}$ Dashes indicate no new growth at these phenological stages.

${ }^{\text {w } U p p e r ~ c a s e ~ l e t t e r s ~ i n d i c a t e ~ m e a n ~ s e p a r a t i o n ~ b e t w e e n ~ p r o d u c t i o n ~ s y s t e m s ~ w i t h i n ~ a ~ p h e n o l o g i c a l ~ s t a g e ~ b y ~ p a i r e d ~} t$ test, $P \leq 0.05$.

Table 4. Comparison of flowering and fruiting between the dormant and nondormant production systems in 'Sharpblue' and 'Wannabe' southern highbush blueberry.

\begin{tabular}{|c|c|c|c|c|}
\hline \multirow[b]{2}{*}{ Parameter $^{2}$} & \multicolumn{2}{|c|}{ 'Sharpblue' } & \multicolumn{2}{|c|}{ 'Wannabe' } \\
\hline & Dormant & Nondormant & Dormant & Nondormant \\
\hline$\overline{\text { Flower bud number }^{2}}$ & $239 b^{y}$ & $297 \mathrm{a}$ & $412 b^{y}$ & $454 \mathrm{a}$ \\
\hline Flower bud density (no./cm) & $0.15 \mathrm{~b}$ & $0.18 \mathrm{a}$ & $0.19 \mathrm{a}$ & $0.22 \mathrm{a}$ \\
\hline Floral budbreak $(\%)^{\mathrm{x}}$ & $71.0 \mathrm{a}$ & $80.2 \mathrm{a}$ & $26.5 \mathrm{~b}$ & $42.0 \mathrm{a}$ \\
\hline Fruit number/plant & $464 \mathrm{~b}$ & $627 \mathrm{a}$ & $241 \mathrm{~b}$ & $574 \mathrm{a}$ \\
\hline Fruit fresh weight (g/plant) & $576 \mathrm{~b}$ & $722 \mathrm{a}$ & $460 \mathrm{~b}$ & $836 \mathrm{a}$ \\
\hline Mean fruit fresh weight (g/fruit) & $1.26 \mathrm{a}$ & $1.16 \mathrm{a}$ & $1.93 \mathrm{a}$ & $1.47 \mathrm{~b}$ \\
\hline
\end{tabular}

${ }^{\mathrm{z}}$ Flower bud number recorded between 15 and 31 Dec. 1996.

${ }^{\mathrm{y}}$ Mean separation within rows and cultivar by paired $t$ test, $P=0.05$.

${ }^{x}$ Total number of flower buds that opened/total number of flower buds.

\section{Materials and Methods}

VEgETATIVE AND REPRODUCTIVE DEVELOPMENT. In June 1996, two container-grown southern highbush blueberry (SHB, Vaccinium corymbosum L. interspecific hybrid) cultivars, Sharpblue and Wannabe, were obtained from two commercial nurseries. These cultivars were selected based on their different patterns of vegetative and floral budbreak. Floral and vegetative budbreak occur concomitantly in 'Sharpblue', whereas floral budbreak precedes vegetative budbreak in 'Wannabe'. The 'Sharpblue' plants were 18 months old 
and $60 \mathrm{~cm}$ tall, and the 'Wannabe' plants were 24 months old and 90 to $120 \mathrm{~cm}$ tall. Root balls on each plant were pruned to about a 12 -L volume and planted in 22-L containers with a medium of 1 peat : 1 perlite (by volume). Plants were acclimated in a $60 \%$ shade house for 2 weeks, then placed outdoors in full sun for the remainder of the experiment. Broken canes and canes growing parallel to the ground were pruned at this time. Between June and Sept. 1996, plants in both systems were fertilized twice weekly with $2.0 \mathrm{~L}$ of Peters $20 \mathrm{~N}-$ 8.8P-16K water soluble fertilizer at $1 \mathrm{~g} \cdot \mathrm{L}^{-1}$ (Grace-Sierra Hort. Products, Co., Milpitas, Calif.).

In Sept. 1996, canopy volumes of 40 plants of each cultivar were determined by measuring height, widest width and a third measurement perpendicular to the widest width. Plants from each cultivar were then blocked into four replications by canopy volume. Within each replication, plants were paired by size, and one plant of each pair was assigned to each production system (i.e., each replication consisted of five plants of each cultivar in each production system). Plants were arranged in east-west rows, on 80 to $120 \mathrm{~cm}$ centers. At this time, fertilization was withheld from plants in the dormant production system, allowing growth to slow and dormancy to occur. The nondormant plants continued to be fertilized as previously described.

Between 15 and 31 Dec. 1996, flower buds were counted on all plants and the few open flowers that were on the plants were removed. On 2 Jan. 1997, pollinating cultivars (SHB cultivars from the University of Florida blueberry breeding program) were placed

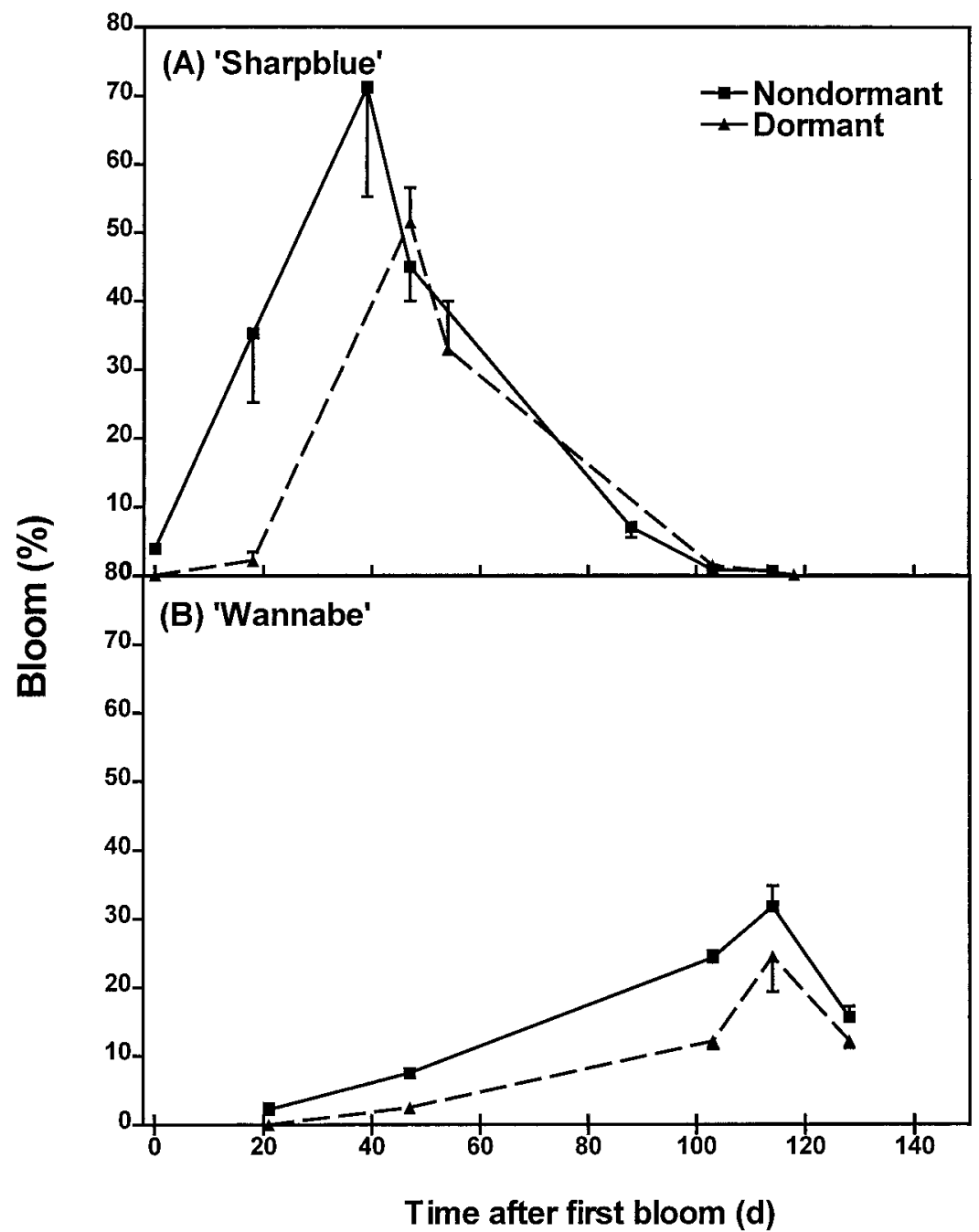

outside around the experimental plants to promote cross-pollination. In mid-April, twice weekly fertilization was resumed on the dormant system plants, as previously described.

Whole plant harvests were planned for different phenological stages during the course of the experiment. One plant pair within each replication was randomly assigned to be harvested at one of the following five phenological stages: before flower bud initiation and differentiation (Pre-FBI), after flower bud initiation and differentiation (FBI), $50 \%$ bloom (when $50 \%$ of the flower buds had opened), $50 \%$ fruit set (when $50 \%$ of the flower buds that opened had set fruit), and immediately after the final fruit harvest. Four plants from each production system (one plant from the assigned pair in each replication) were harvested at each phenological stage. In some cases, the calendar dates of the phenological stages, and therefore the whole-plant harvest dates, differed between the production systems. Many flower buds on 'Wannabe' plants failed to open, thus, there are no $50 \%$ bloom whole-plant harvest data. The dates of each harvest are shown in Table 1.

At each harvest, plants were divided into vegetative and reproductive organs. Fresh weight (FW), dry weight (DW), and number or area, if applicable, were measured for each organ type. Leaf area was measured using a LI-portable leaf area meter (LI-3000, LICOR, Lincoln, Nebr.). Lengths of all plant canes (main stems arising from the crown of the plant) and side stems from these canes were measured and recorded as total cane length. Root FW was recorded after roots were washed free of the potting medium. Plant parts were dried at $70{ }^{\circ} \mathrm{C}$ until a constant DW was established. Dried roots were separated into fibrous $(<1 \mathrm{~mm}$ diameter) and thick roots ( $>1 \mathrm{~mm}$ diameter) and DW for each type was measured.

Fruit on both cultivars began to ripen in mid-March. Between 18 Mar. and 20 June 1997, ripe fruit was harvested every 3 to $5 \mathrm{~d}$. Fruit number, FW, and DW were recorded.

Carbohydrate analysis. Dried canes (not including new spring growth), fibrous roots, and thick roots were ground to pass a 20 mesh (1.27-mm mesh) screen. Cane and root soluble $\mathrm{CH}_{2} \mathrm{O}$ were extracted from $50 \mathrm{mg}$ tissue samples by shaking for $20 \mathrm{~min}$ in $5 \mathrm{~mL}$ cold $80 \%$ ethanol. Extracts were centrifuged at $1000 g_{n}$ for 10 min, the supernatant decanted, and the pellet reextracted twice. The supernatants were combined and final volume was measured. Sample pigment was removed by adding $25 \mathrm{mg}$ activated charcoal, followed by $2 \mathrm{mg}$ polyvinylpolypyrrolidone(PVPP). Soluble sugars were assayed using the phenol-sulfuric acid assay (Chaplin and Kennedy, 1994). An external ${ }^{14} \mathrm{C}$ sucrose standard was used to determine $\mathrm{CH}_{2} \mathrm{O}$ recovery.

Tissue starch content was determined by suspending the pellets from the $80 \%$ ethanol extraction in $2 \mathrm{~mL}$ $0.2 \mathrm{~N} \mathrm{KOH}$ and boiling for $30 \mathrm{~min}$. After boiling, sample $\mathrm{pH}$ was adjusted to 4.5 by adding $1.0 \mathrm{~mL} 1 \mathrm{~m}$ acetic acid.

Fig. 1. (A) 'Sharpblue' and (B) 'Wannabe' bloom periods for the dormant and nondormant production systems, Winter and Spring 1996-97. (means $\pm \mathrm{SE}, \mathrm{n}=4$, SE bars present only when larger than symbol). Percent bloom is the number of open flower buds/flower bud number. Days after first bloom: 0 (9 Dec. 1996), 20 (29 Dec. 1996), 40 (18 Jan. 1997), 60 (7 Feb. 1997), 80 (27 Feb. 1997), 100 (19 Mar. 1997), 120 (8 Apr. 1997), and 140 (28 Apr. 1997). Floral budbreak began 9 Dec. and 29 Dec. 1996 for nondormant and dormant 'Sharpblue' plants, respectively. Floral budbreak began on 29 Dec. 1996 and 12 Jan. 1997 for nondormant and dormant 'Wannabe' plants, respectively. 
Tissue starch was digested by adding $1.0 \mathrm{~mL}$ Rhizopus amyloglucosidase (118 units $/ \mathrm{mL}$ ) and $1.0 \mathrm{~mL}$ barley malt $\alpha$ amylase (4 units/mL) (Sigma Chemical Co., St. Louis), each dissolved in $0.2 \mathrm{M}$ calcium acetate buffer ( $\mathrm{pH} 4.5$ ) (Scholes et al., 1996). Samples were incubated in a shaking water bath for $24 \mathrm{~h}$ at $37{ }^{\circ} \mathrm{C}$. After incubation, samples were centrifuged as before, the supernatant decanted and volumes determined. The pellets were redigested as described above. Pigment was removed from supernatants with $25 \mathrm{mg}$ activated charcoal and the glucose liberated from the starch during each digestion was assayed by the phenol-sulfuric acid assay. The assay results from each digestion were summed and statistically analyzed.

The experimental design for each cultivar was a randomized complete block design comparing the two production systems at different phenological stages. There were four blocks and each block was considered a replication. Due to differences in plant responses, comparisons were made only within each cultivar. Data were subjected to analysis of variance and mean separation, using Duncan's multiple range test (SAS Inst. Inc., Cary, N.C.). In cases where data were missing, analysis was done using least square means. Means were compared across phenological stages and production systems, as well as between production systems at each individual phenological stage.

\section{Results}

VEGETATIVE CHARACTERISTICS. Leaf area and DW of leaves formed during the 1996 growing season (i.e., old leaves) decreased in both production systems and both cultivars from Oct. 1996 through fruit harvest in May 1997 (Tables 2 and 3). However, plants in the nondormant system retained their 1996 leaves longer than plants in the dormant system. This was particularly true for 'Sharpblue', where plants in the nondormant system retained greater 1996 leaf area and DW compared with plants in the dormant system through 50\% fruit set (March to April 1997) (Table 2). The patterns of leaf FW changes were similar to those seen in leaf DW data (data not presented).

'Sharpblue' plants in the nondormant system broke vegetative bud first, beginning 9 Jan. 1997. This was followed by vegetative budbreak in 'Sharpblue' dormant system plants (1 Feb. 1997), 'Wannabe' dormant system plants (21 Mar. 1997), and finally 'Wannabe' nondormant system plants (2 Apr. 1997). There was a lag in leaf and shoot development on 'Sharpblue' plants in the nondormant system, such that the Spring 1997 leaf (new leaf) area and DW were greater in the dormant system compared with the nondormant system at both $50 \%$ bloom and 50\% fruit set (Table 2). At final plant harvest, 'Sharpblue' new leaf area was greater in the

Fig. 2. Fruit yield and percent of total fruit harvest for (A) nondormant and (B) dormant production systems in 'Sharpblue' southern highbush blueberry (means $\pm \mathrm{SE}$, $\mathrm{n}=15$, sE bars present only when larger than symbol). nondormant system compared with dormant system plants, although new leaf DW was similar. This apparent anomaly was due to loss of some leaf samples during drying, and subsequent use of the more conservative least square means test to determine differences. 'Wannabe' new leaf area and DW increased in both systems between the FBI and final plant harvests, but were similar between systems at all phenological stages (Table 3).

Plant volume increased in dormant system plants of 'Sharpblue' between Pre-FBI and 50\% bloom, then remained steady (Table 2). However, the volume of 'Sharpblue' plants in the nondormant system did not increase until after $50 \%$ bloom, due to the lag in new vegetative development compared with the dormant system and the large variability found in 'Sharpblue' plants of both systems at this harvest. Plant volumes were similar for 'Wannabe' plants between production systems at all phenological stages (Table 3). New cane DW in 'Sharpblue' was greater in the nondormant compared with the dormant system at the final plant harvest, although cane length was similar (Table 2). There were no differences in new cane length or DW between production systems in 'Wannabe' (Table 3).

The relative proportion of fibrous and thick roots remained the same for both cultivars at each harvest, thus only whole root data are provided. 'Sharpblue' root DW was similar in both production systems at all whole-plant harvests except for the final harvest, by which time plants in the dormant system had greater root DW than plants in the nondormant system (Table 2). No difference in root

\section{'Sharpblue'}

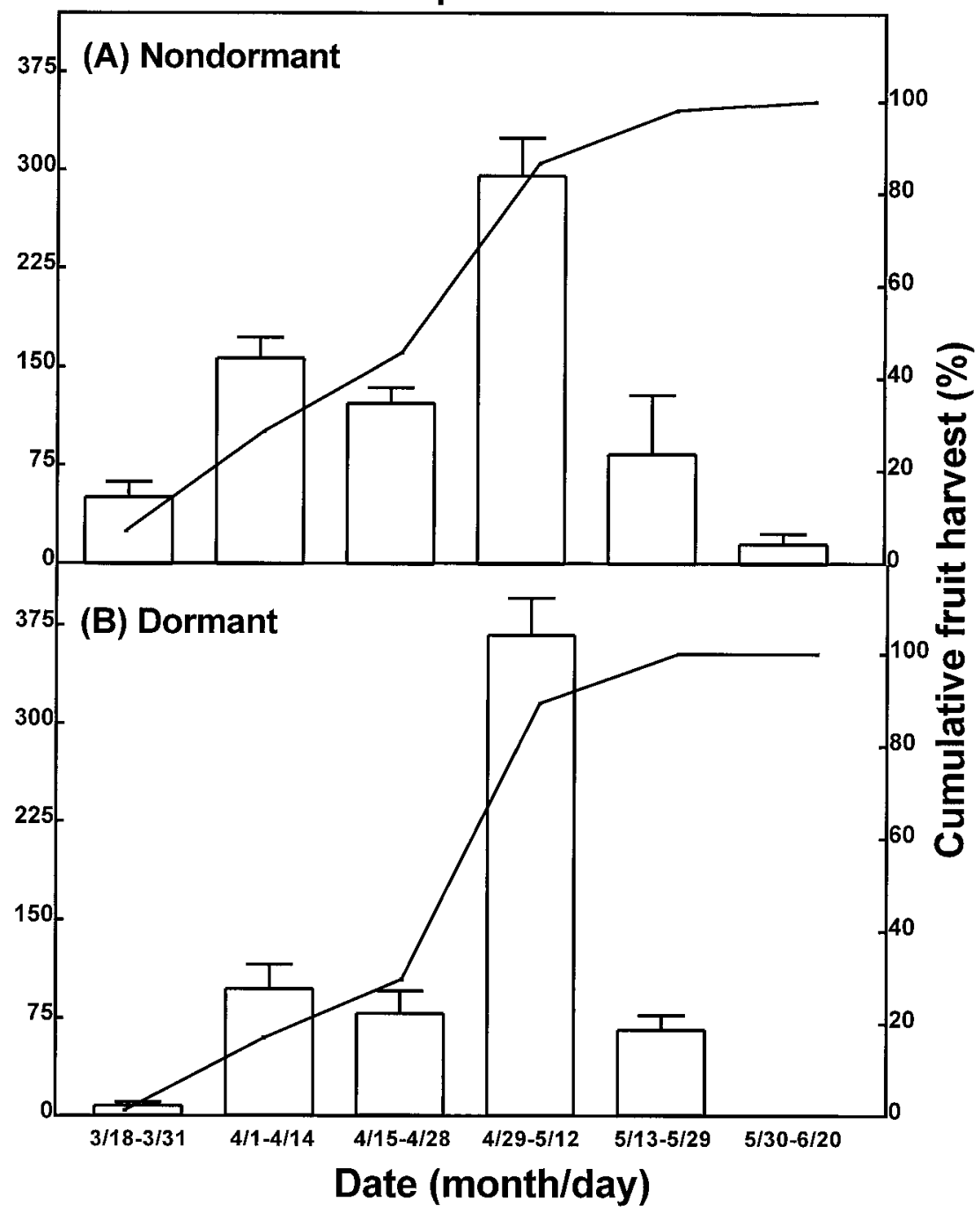


DW was found between production systems or phenological stage in 'Wannabe' (Table 3).

REPRODUCTIVE CHARACTERISTICS. Flower buds were first observed in both cultivars in late Aug. 1996 (daylength $\approx 12 \mathrm{~h} 50 \mathrm{~min}$.), before the production system differences were imposed. By 31 Dec. 1996, flower bud number was greater in the nondormant system plants of both cultivars compared with the dormant system plants (Table 4). Flower bud density (buds per cm cane length) was greater in 'Sharpblue' nondormant system vs. dormant system plants, but flower bud density in 'Wannabe' was not different between systems.

Floral budbreak occurred earlier in plants in the nondormant than the dormant production system for both cultivars (Fig. 1A and B). 'Sharpblue' floral budbreak began 9 Dec. 1996 in the nondormant system and 29Dec. in the dormant system. 'Sharpblue' nondormant system and dormant system plants reached $50 \%$ bloom on $\approx 5$ Jan. and 24 Jan. 1997, respectively. 'Wannabe' floral budbreak and 50\% bloom were difficult to ascertain due to the low number of flower buds open at any particular time, a trait characteristic of this cultivar. Open flowers were first observed in the nondormant 'Wannabe' system 28 Dec. 1996 and in the dormant system 12 Jan. 1997. Overall, floral budbreak percentage was higher for 'Wannabe' plants in the nondormant compared with dormant system, whereas no differences in total percent budbreak were observed between systems in 'Sharpblue' plants (Table 4).

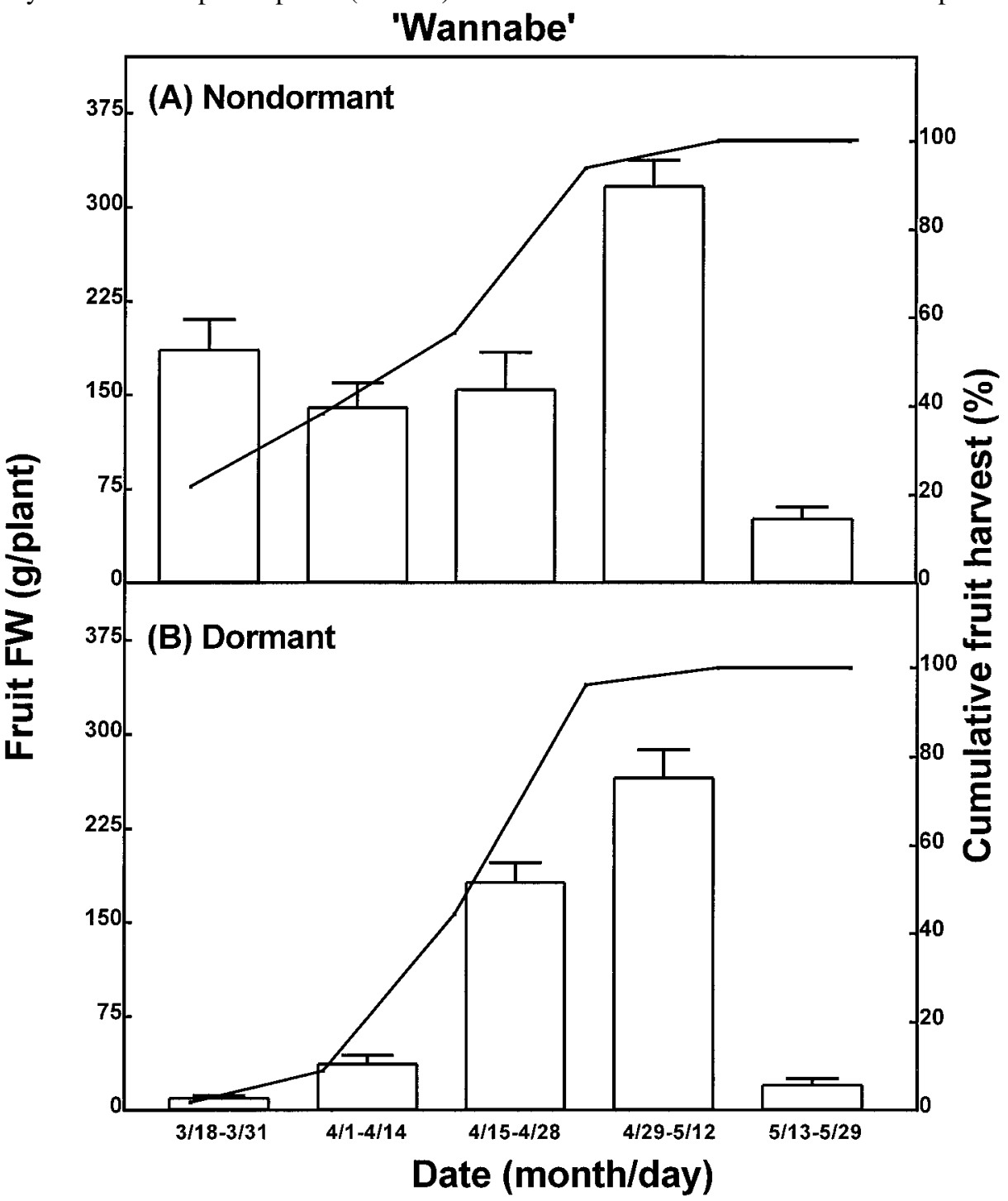

Ripe fruit were harvested from plants in both cultivars and production systems beginning 18 Mar. 1997 (Fig. 2A and B, Fig. 3A and B). Fruit harvest in dormant system 'Sharpblue' plants was concentrated between 29 Apr. and 12 May, while fruit harvest from plants in the nondormant system was less concentrated, extending from March through May. Total fruit FW and number were significantly greater in nondormant system 'Sharpblue' compared with dormant system plants, whereas mean fruit FW was not different between production systems (Table 4). Fruit harvest in 'Wannabe' was complete by the end of May in both systems. Total fruit FW and number were significantly greater in nondormant compared with dormant system 'Wannabe' plants (Table 3). However, mean fruit FW was greater in dormant compared with nondormant 'Wannabe' plants (Table 3). Early yield (through 14 Apr.) in the nondormant system for both cultivars was much greater than in the dormant system (Figs. 2 and 3). This was especially true for 'Wannabe', where $40 \%$ of the fruit was harvested by 14 Apr. in the nondormant system, compared with $20 \%$ in the dormant system.

Cane and root carbohydrate analyses. Phenological patterns of $\mathrm{CH}_{2} \mathrm{O}$ concentration (starch and soluble sugar) in canes and roots were similar between production systems in both cultivars, although concentrations were often greater in the dormant than nondormant system (Fig. 4). The pattern of total $\mathrm{CH}_{2} \mathrm{O}$ content in roots and canes was similar to the pattern of $\mathrm{CH}_{2} \mathrm{O}$ concentrations, and thus is not presented. In both production systems and cultivars, cane and root $\mathrm{CH}_{2} \mathrm{O}$ concentrations increased between pre-FBI and FBI, then decreased between FBI and $50 \%$ fruit set.

In general, total soluble sugars in canes and roots did not differ markedly between production systems within a phenological stage (Fig. 4). Differences that were noted were also generally reflected in differences in starch concentration. Accumulation of cane starch was greater in 'Sharpblue' plants in the dormant system compared with the nondormant system between pre-FBI and FBI, and higher starch concentrations were maintained incanes of the dormant system plants through $50 \%$ bloom. Following 50\% bloom, cane starch concentrations in dormant system plants decreased more rapidly than in nondormant system plants, resulting in greater starch concentrations in nondormant system plants by $50 \%$ fruit set. By fruit harvest, however, cane starch concentrations were similar between the two systems.

Starch accumulation in 'Sharpblue' roots was similar in both systems between the preFBI and FBI plant harvests. Root starch concentrations in dormant system plants decreased significantly between FBI and 50\% bloom, and continued to decrease through $50 \%$ fruit set. In contrast, root starch concentrations in nondormant system plants did not decrease until the period between bloom and $50 \%$ fruit set. Root starch concentrations increased in

Fig. 3. Fruit yield and percent of total fruit harvest for (A) nondormant and (B) dormant production systems in 'Wannabe' southern highbush blueberry (means $\pm \mathrm{sE}, \mathrm{n}$ $=19$, SE bars present only when larger than symbol). 


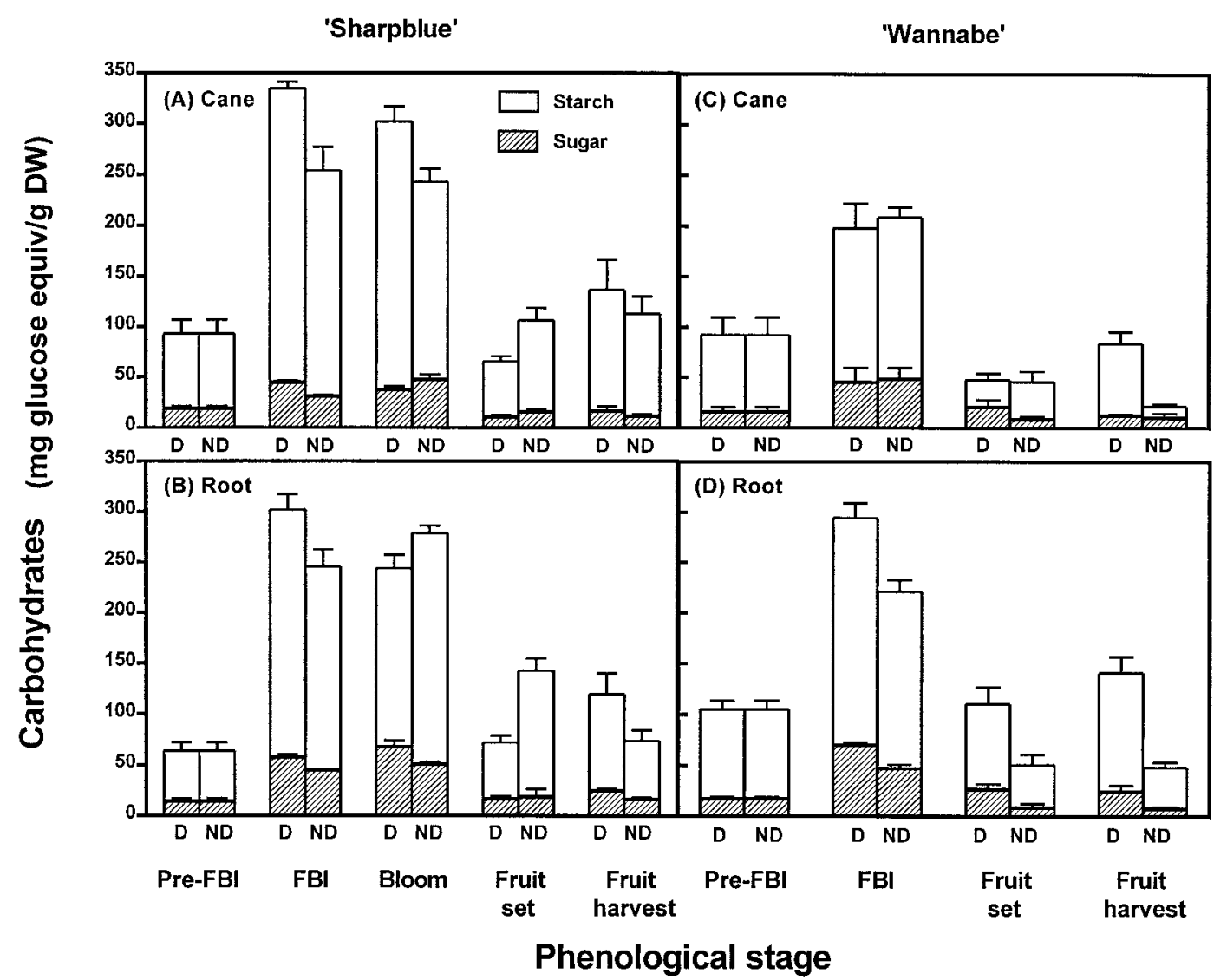

coupled with vegetative and reproductive growth responses, suggest that the nondormant production system did, in fact, increase available $\mathrm{CH}_{2} \mathrm{O}$ compared with the dormant production system. The increased total plant DW observed in nondormant compared with dormant 'Sharpblue' alsoindicates that $\mathrm{CH}_{2} \mathrm{O}$ availability increased in the nondormant compared with the dormant system.

The striking vegetative difference between the two production systems was increased leaf retention of the nondormant compared with the dormant system plants. Since decreases in photosynthetic rates are found in leaves as they age (Reader, 1978; Reich et al., 1992), increased leaf retention does not necessarily mean the leaf continues to be a net contributor to the $\mathrm{CH}_{2} \mathrm{O}$ pool of the plant. However, Heinicke (1934) reported that

Fig. 4. 'Sharpblue' (A) cane and (B) root and 'Wannabe' $(\mathbf{C})$ cane and $(\mathbf{D})$ root carbohydrate concentrations in dormant and nondormant plants measured between October 1996 and June 1997 at different phenological stages (means \pm SE, across all harvests and production systems within a cultivar, $n=4$, SE bars present only when larger than symbol). $\mathrm{D}=$ dormant system, $\mathrm{ND}=$ nondormant system. Pre$\mathrm{FBI}=$ before flower bud initiation and differentiation, FBI $=$ after flower bud initiation and differentiation, Bloom $=50 \%$ of the flower buds were open, Fruit set $=50 \%$ of the flower buds that opened set fruit, and Fruit harvest $=$ immediately after final fruit harvest. See Table 1 for exact calendar dates.

dormant system plants between fruit set and fruit harvest but decreased in nondormant system plants during the same period. At $50 \%$ bloom and $50 \%$ fruit set, root starch concentrations were greater in the nondormant compared with the dormant system plants.

Cane starch concentrations in 'Wannabe' were similar between the two production systems at all phenological stages except fruit harvest, where cane starch concentrations in dormant system plants were greater than in nondormant system plants (Fig. 4C). In contrast, root starch concentrations were greater in dormant system compared with nondormant system plants at FBI and fruit harvest.

Total plant DW (including ripe fruit) at final harvest was greater for nondormant compared with dormant 'Sharpblue' plants (Fig. 5). However, no DW differences between systems were found in 'Wannabe'.

\section{Discussion}

The hypothesis tested in the present experiment was that longer leaf retention of plants grown in the nondormant compared with the dormant production system increased $\mathrm{CH}_{2} \mathrm{O}$ availability, resulting in an increase in fruit yield the following season. Although increases in $\mathrm{CH}_{2} \mathrm{O}$ availability in the nondormant system were not definitively shown in the current study, the patterns of $\mathrm{CH}_{2} \mathrm{O}$ reserve levels, autumn $\mathrm{N}$ applications increased apple [Malus sylvestris (L.) Mill. Var domestica (Borkh.) Mansf.] leaf retention and leaf photosynthetic rates compared with control plants, which did not receive fall $\mathrm{N}$ applications and exhibited decreased leaf photosynthetic rates during this time. In the present study, photographs and observations document that the leaves of the nondormant system plants maintained a dark green color throughout the winter (December to March) in contrast to nonabscised leaves on the dormant system plants, which exhibited significant pigment loss during this time.

Although the assumption that increased leaf retention resulted in increased $\mathrm{CH}_{2} \mathrm{O}$ availability in nondormant system plants was reflected in total plant DW in 'Sharpblue', it was not reflected in the $\mathrm{CH}_{2} \mathrm{O}$ reserve levels in either cultivar. In general, similar or lower concentrations of reserve $\mathrm{CH}_{2} \mathrm{O}$ were found in the canes and roots of the nondormant compared with the dormant system plants between FBI and bloom. However, increased flower bud number in the nondormant system compared with the dormant system plants would represent an alternative sink to reserve $\mathrm{CH}_{2} \mathrm{O}$ accumulation. Thus, increased $\mathrm{CH}_{2} \mathrm{O}$ availability in nondormant system plants presumably was used to increase flower bud initiation and development, rather than increase the $\mathrm{CH}_{2} \mathrm{O}$ reserve pools. This is supported by additional work, in which $\mathrm{CH}_{2} \mathrm{O}$ reserve pools in roots of 'Sharpblue' increased significantly in response to flower bud removal in the fall (Swain and Darnell, unpublished data). Similarly, autumn $\mathrm{N}$ applications not only increased leaf retention and photosynthetic rates in apple, peach [Prunus persica (L.) Batsch], and pear (Pyrus communis L.), but also decreased reserve $\mathrm{CH}_{2} \mathrm{O}$ accumulation and increased reproductive development, compared with control plants (Delap, 1967; Khemira et al., 1998; Stassen et al., 1981b).

The increased $\mathrm{CH}_{2} \mathrm{O}$ availability presumed to occur in the nondormant system compared with the dormant system plants during the FBI period appeared to be allocated primarily to repro- 


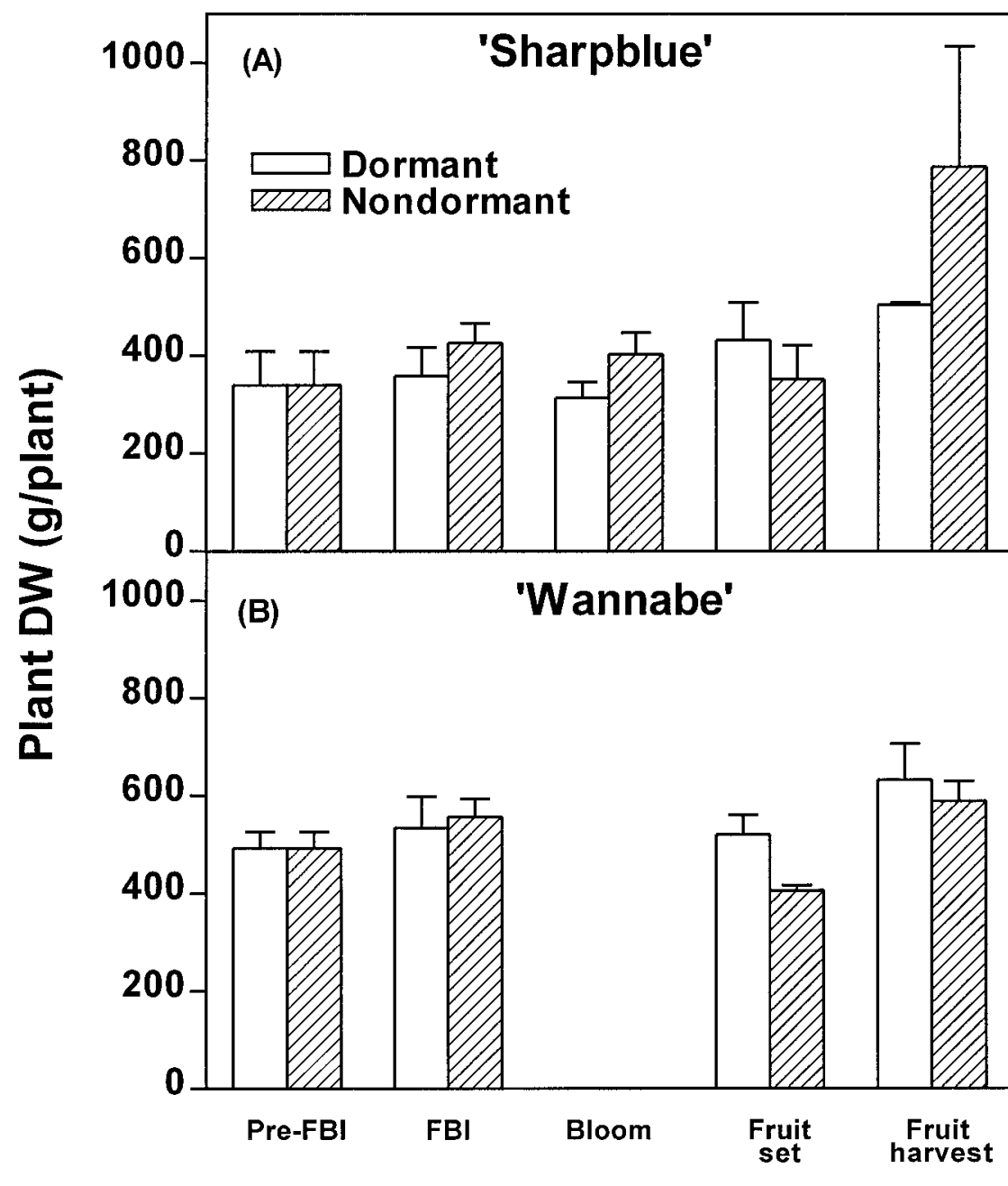

Phenological stage

Fig. 5. Total plant DW (including fruit) at each plant harvest for dormant and nondormant (A) 'Sharpblue' and (B) 'Wannabe' southern highbush blueberry (means \pm sE, $n=4$, sE bars present only when larger than symbol). Pre-FBI = before flower bud initiation and differentiation, FBI = after flower bud initiation and differentiation, Bloom $=50 \%$ of the flower buds were open, Fruit set $=50 \%$ of the flower buds that opened set fruit, and Fruit harvest = immediately after final fruit harvest. See Table 1 for exact calendar dates.

ductive development, not vegetative growth. In general, vegetative growth was not different between production systems for either cultivar. This is likely due to photoperiodic effects on blueberry growth. Flower bud initiation is a well documented, short day response in many Vaccinium sp., thus, as photoperiod decreases in the fall, there is an increase in flower bud initiation and a concomitant decrease in vegetative growth in blueberry (Aalders and Hall, 1964; Hall et al., 1963; Hall and Ludwig, 1961). In the present experiment, the natural photoperiod was $\approx 12 \mathrm{~h}$ when fertilization was withheld in the dormant system. The minimum photoperiod during the winter in Gainesville $\left(29.5^{\circ} \mathrm{N}\right.$ lat. $)$ is $\approx 10 \mathrm{~h}$. It is probable that flower bud initiation continued in the nondormant system plants during much of the fall and winter, due to decreased photoperiods, mild temperatures, and leaf retention. Since leaves are required to perceive photoperiod in blueberry (Lyrene, 1992), flower bud initiation and development would continue in the nondormant plants, but not in the dormant system plants due to their leafless condition. Although not tested, the photoperiodic effect on flower bud initiation in the nondormant system plants may be more influential than the $\mathrm{CH}_{2} \mathrm{O}$ effect.

Plants in the nondormant production system exhibited earlier and more extended blooming than plants in the dormant production system. Similarly, autumn $\mathrm{N}$ applications in apple and peach advanced floral budbreak, although no information on bloom period duration was reported (Delap, 1967; Stassen et al., 1981a; Williams, 1963). These authors speculated the early floral budbreak was due to advanced development of the flower buds (Delap, 1967; Williams, 1965). The earliness of bloom in nondormant compared with dormant system blueberry plants may be a reflection of advanced floral development in the nondormant system. The extended bloom period in the nondormant system plants is probably a reflection of the extended flower bud initiation period throughout the fall and winter.

Earlier blooming in the nondormant production systems was reflected in an increase in early yields compared with the dormant production systems. The extended fruit harvest season in the nondormant systems, however, was probably due to the extended bloom periods. The increased yield in both cultivars in the nondormant system compared with dormant system plants was due primarily to the increase in flower bud number, and in 'Wannabe', an increase infloral budbreak percentage. The increase in flower bud number and the subsequent increase in fruit number in the nondormant system plants did not affect fruit FW in 'Sharpblue'. It appears that 'Sharpblue' plants in the nondormant system may have had sufficient $\mathrm{CH}_{2} \mathrm{O}$ available to increase flower bud number without deleteriously affecting flower bud cell division, which is the primary determinant of fruit size in blueberry (Swain, 1999). This would result in increased fruit number without a concomitant decrease in fruit cell number and fruit FW. On the other hand, mean fruit FW in nondormant system 'Wannabe' was less than in dormant system plants. This inverse relationship between fruit number and fruit size has been reported in highbush blueberry (Siefker and Hancock, 1986), as well as many other crops (Ingles et al., 1995; Weinberger, 1941). Differences in production system effects on fruit FW between cultivars are probably due to a combination of a greater difference in fruit number between the 'Wannabe' production systems compared with the 'Sharpblue' production systems, as well as an overall larger fruit size in 'Wannabe' than is found in 'Sharpblue'.

The present study clearly shows that flower bud initiation and fruit yield increase in the nondormant compared with the dormant blueberry production system, when both systems are grown under the same environmental conditions. Increased $\mathrm{CH}_{2} \mathrm{O}$ availability, as well as a longer period for perception of short days, probably played a role in increasing flower bud initiation (and subsequent yield), however, the relative importance of these factors is unknown, and may be cultivar dependent.

\section{Literature Cited}

Aalders, L.E. and I.V. Hall. 1964. A comparison of flower-bud development in the lowbush blueberry, Vaccinium angustifolium Ait. under greenhouse and field conditions. Proc. Amer. Soc. Hort. Sci. 85:281-284. Chaplin, M.F. and J.F. Kennedy. 1994. Carbohydrate analysis: A practical 
approach. $2^{\text {nd }}$ ed. IRL Press at Oxford Univ. Press, Oxford, United Kingdom.

Delap, A.V. 1967. The effect of supplying nitrate at different seasons on the growth, blossoming and nitrogen content of young apple trees in sand culture. J. Hort. Sci. 42:149-167.

Hall, I.V., D.L. Craig, and L.E. Aalders. 1963. The effect of photoperiod on the growth and flowering of highbush blueberry. Proc. Amer. Soc. Hort. Sci. 82:260-263.

Hall, I.V. and R.A. Ludwig. 1961. The effects of photoperiod, temperature, and light intensity on the growth of the lowbush blueberry (Vaccinium angustifolium Ait.). Can. J. Bot. 39:1733-1739.

Heinicke, A.J. 1934. Photosynthesis in apple leaves during late fall and its significance in annual bearing. Proc. Amer. Soc. Hort. Sci. 32:77-80.

Ingles, P., G. Barbera, T. La Mantia, and S. Portolano. 1995. Crop production, growth, and ultimate size of cactus pear fruit following fruit thinning. HortScience 30:227-230.

Khemira,H., A.N. Azarenko, D. Sugar, and T.L. Righetti. 1998. Postharvest nitrogen application effect on ovule longevity of 'Comice' pear trees. J. Plant Nutr. 21:405-411.

Lyrene, P.M. 1992. Early defoliation reduces flower bud counts on rabbiteye blueberry. HortScience 27:783-785.

Reader, R.J. 1978. Contribution of overwintering leaves to the growth of three broad-leaved, evergreen shrubs belonging to the Ericaceae family. Can. J. Bot 56:1248-1261.

Reeder, R.K., R.L. Darnell, and T.A. Obreza. 1994. Establishment of an evergreen high density blueberry planting in Southwest Florida. Proc. Fla. State Hort. Soc. 107:326-328.

Reeder, R.K., T.A. Obreza, and R.L. Darnell. 1998. Establishment of a non dormant blueberry (Vaccinium corymbosum hybrid) production system in a warm winter climate. J. Hort. Sci. Biotechnol. 73:655-663.

Reich, P.B., M.B. Walters, and D.S. Ellsworth. 1992. Leaf life-span in relation to leaf, plant, and stand characteristics among diverse ecosystems. Ecol. Monogr. 62:365-392.

Scholes, J., N. Bunock, R. Wilde, and S. Rolfe. 1996. The impact of reduced vacuolar invertase activity on the photosynthetic and carbohydrate metabolism of tomato. Planta 200:265-272.

Sharpe, R.H. and W.B. Sherman. 1971. Breeding blueberries for low chilling requirement. HortScience 6:145-147.

Siefker, J.H. and J.F. Hancock. 1986. Yield component interactions in cultivars of the highbush blueberry. J. Amer. Soc. Hort. Sci. 111:606608.

Stassen, P.J.C., D.K. Styrdom, and H.W. Stindt. 1981a. Seasonal changes in carbohydrate fractions of young 'Kakamas' peach trees. Agroplantae 13:47-53.

Stassen, P.J.C., J.H. Terblanche, and D.K. Styrdom. 1981b. The effect of time and rate of nitrogen application on development and composition of peach trees. Agroplantae 13:55-61.

Swain, P.A.W. 1999. Source limitations to reproductive development in dormant vs nondormant blueberry production systems. MS thesis. Univ. Fla., Gainesville.

Weinberger, J.H. 1941. Studies on time of peach thinning from blossoming to maturity. Proc. Amer. Soc. Hort. Sci. 38:137-140.

Williams, R.R. 1963. The effect of nitrogen on the self-fruitfulness of certain varieties of cider apples. J. Hort. Sci. 38:52-60.

Williams, R.R. 1965. The effect of summer nitrogen applications on the quality of apple blossom. J. Hort. Sci. 40:31-41. 